\title{
Carpology of some East Asian Cardueae (Asteraceae)
}

\author{
by \\ E.V. Zarembo \& E.V. Boyko \\ Laboratory of plant chemotaxonomy, Pacific Institute of Bioorganic Chemistry, Far-East Division, \\ Russian Academy of Sciences 690022, 100-letiya Vladivostoky Ave., 159, Vladivostok, Russia. zarelena@rambler.ru
}

\begin{abstract}
Zarembo, E.V. \& Boyko, E.V. 2008. Carpology of some East Asian Cardueae (Asteraceae). Anales Jard. Bot. Madrid 65(1): 129-134.

The present paper deals with the morphological, anatomical structure of achenes in the East Asian species of Rhaponticum, Klasea Serratula and Synurus. The structure of pericarp epidermal cells, mesocarp, has been described, as well as the structure of testa epidermal cells. The specific characters of the genera, as well as the identification characters of the species, are described.
\end{abstract}

Keywords: Asteraceae, Cardueae, achene, anatomic structure.

\section{Introduction}

The morphological and anatomic structure of achenes in the tribe Cardueae Cass. is of great importance for hierarchial classification of the superspecific taxa. One of the first papers on achene anatomy of Asteraceae was published by Lavialle (1912), who had studied about 83 species of 15 genera: Arctium L., Carduncellus Adans., Carduus L., Carthamus L., Centaurea L., Cnicus L., Cousinia Cass., Crupina Cass., Cynara L., Galactites Moench, Jurinea Cass., Onopordum L.,Saussurea DC., Serratula L. and Silybum Adans. Major achene characteristics, including the testa's epidermis pattern, of the representatives of the tribe were described in details. At the beginning of achene development the epidermal cells are isodiametrical in shape, in the course of its development they stretch in the radial direction, their walls get greatly sclerified. The radial elongation begins near the micropyle and spreads towards the subchalazal region. There are no cells directed perpendicularly to the tangent, they are inclined to the micropyle. Lavialle also paid great attention to specific structures

\section{Resumen}

Zarembo, E.V. \& Boyko, E.V. 2008. Carpología de algunas Cardueae (Asteraceae) de Asia oriental. Anales Jard. Bot. Madrid 65(1): 129-134 (en inglés).

El presente artículo se refiere a las características morfológicas, la estructura anatómica de los aquenios en las especies de Rhaponticum, Klasea Serratula y Synurus en Asia oriental. Se han descrito la estructura de células epidérmicas del pericarpio, y el mesocarpio, así como la de la testa de las células epidérmicas. También quedan descritos los caracteres específicos de los géneros, así como los caracteres de identificación de las especies.

Palabras clave: Asteraceae, Cardueae, aquenio, estructura anatómica.

of the achene's integuments - crystals and secretory ducts. Calcium oxalate crystals were revealed in the inner parenchyma. Occurrence of calcium oxalate crystals in the inner parenchyma layer of pericarp in the Cardueae had been mentioned (Hanausek, 1911; Dormer, 1961; Singh \& Pandey, 1984) as well.

The morphological and anatomic structure of achenes has been used in solving some taxonomic problems in the tribe Cardueae (Dittrich, 1968a; 1968b; 1968c, 1970, 1977, 1985). Besides, there are quite a number of papers that cover morphological and anatomic structure of achenes in individual species of the tribe or in groups of species (Fourment \& al., 1956; Gochu, 1973; Karawya \& al., 1974; Chargoglyan, 1975; Namba \& al., 1975; Pandey \& Singh, 1977; Cherneva \& Shurukhina, 1979; Wagenitz \& al., 1982; Pérez-García \& Duran; 1987; Chernik, 1984; Häffner, 2000).

\section{Materials and methods}

We have studied morphology and anatomy of achenes of East Asian representatives of the subtribe 
Centaureinae (Cass.) Dumort: Klasea Cass., Rhaponticum Vaill. and Serratula (Leuzea DC., Stemmacantha (Cass.) and subtribe Carduinae (Cass.) Dumort. -Synurus Iljin. In the Far East of Russia the genus Serratula is represented by $S$. manshurica Kitag. The genus Klasea is represented by twos species: Klasea centauroides (L.) Cass. and K. komarovii Iljin. The genus $R$ baponticum is represented by two taxa: $R h$. uniflorum (L.) DC. and Rh. satzyperovii Soskov. The genus Synurus is represented by 1 species, Synurus deltoides (Ait.) Nakai.

For the micromorphological observations, achenes were softened in a solution of glycerine, ethanol and water (1:1:1) for a few days, embedded in paraffin and cut by microtom. Sections were cut to a thickness of 8 $15 \mu \mathrm{m}$. Longitudinal and cross sections were stained in safranin.

\section{Results and Discussion}

\section{Achene integument}

Achenes of the subtribe Cardueae are characterized by thick multilayer integuments and a palisade row of macrosclereids, which clearly sets apart the species of the subtribes Cardueae and Centaureinae from the representatives of the subtribe Carlininae.

Achenes of the studied species of Klasea and Serratula are characterized by equally developed pericarp and testa. The general thickness of the mature achene integuments varies from 100 to $230 \mu \mathrm{m}$ due to the different thickness of pericarp. In the region of the large strands of mechanic tissue located around conducting bundles, the thickness of pericarp varies from 60-65 (S. manshurica) to $135 \mu \mathrm{m}$ (Klasea centauroides), and from 25-40 (Serratula manshurica) to $80 \mu \mathrm{m}$ (Klasea centauroides) in the intercostals area (Figs. 2, 3, 4).

Achenes of Synurus deltoides are characterized by very thick pericarp and comparatively thin testa. The embryo is mostly protected by pericarp and to a lesser extent by testa. The thickness of mature achene integuments varies from $485-540 \mu \mathrm{m}$ in the intercostals area, and to $640-660 \mu \mathrm{m}$ on the ribs due to the different thickness of pericarp, which determines the occurrence of numerous longitudinal ribs on the achene surface (Fig. 1).

The studied representatives of Rhaponticum are characterized by relatively thick pericarp and thick testa. The embryo is equally protected by pericarp and testa. The mature achene integument thickness varies due to the different thickness of pericarp, which determines the occurrence of numerous longitudinal ribs on the achene surface. In the region of the large strands of mechanic tissue located around conducting bundles the thickness of the achene integuments reaches $270-360 \mu \mathrm{m}$ on the ribs, and from 200 to $270 \mu \mathrm{m}$ in the intercostals area. In the upper part of achene the thickness of the integument is 500$590 \mu \mathrm{m}$ - due to enlargement of parenchyma cells in the peripheral region of the pericarp, as a result denticles on the margin of the achene apex are formed. The pericarp thickness varies from $25-80 \mu \mathrm{m}$ in the intercostals area, and to $100-160 \mu \mathrm{m}$ on the ribs (Fig. 5).

\section{Topography of epidermal cells of pericarp}

Mature pericarp is represented by exocarp and mesocarp. In the species of Serratula the exocarp is formed by one row of cube-shaped epidermal cells $(S$. manshurica). In Klasea these cells are oval (S. centau-
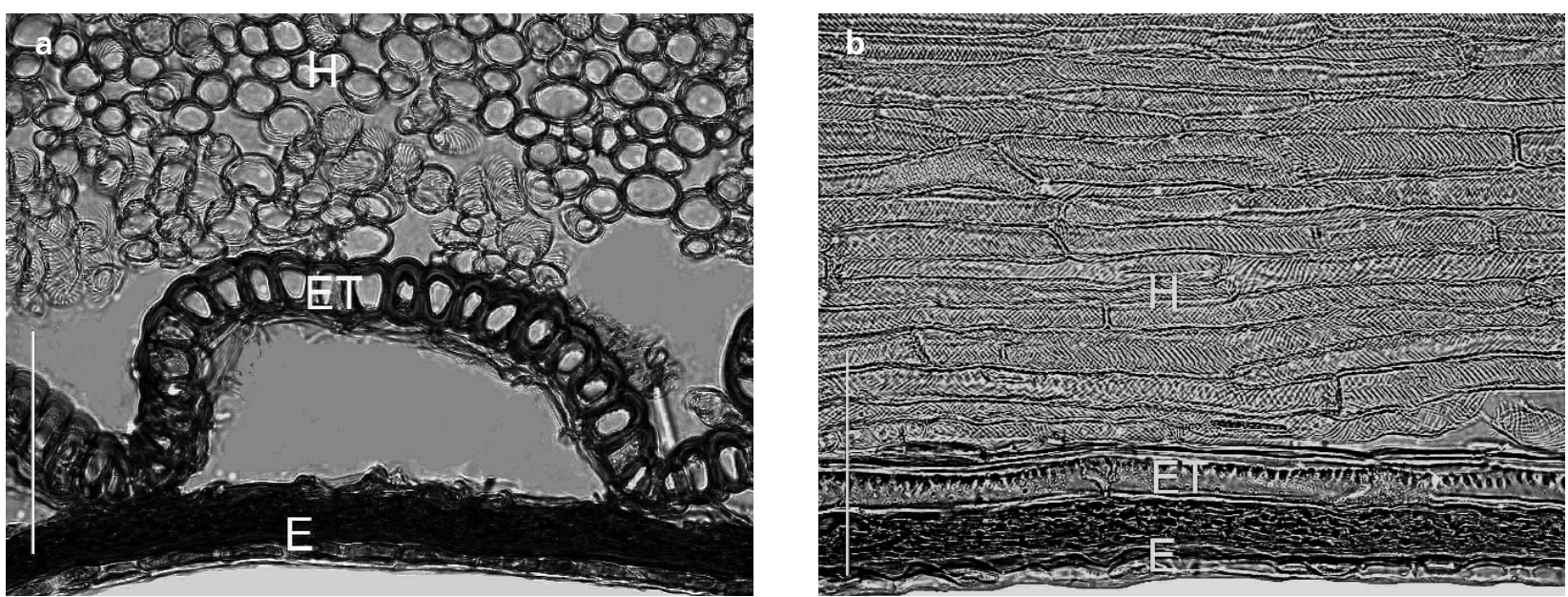

Fig. 1. Synurus deltoides: a, cross section of achenes; $\mathbf{b}$, longitudinal section of achenes; ET, epidermal cells of testa; $E$, endosperm, $\mathrm{H}$, hydrocytes. Scale bar: 0,1 mm. 

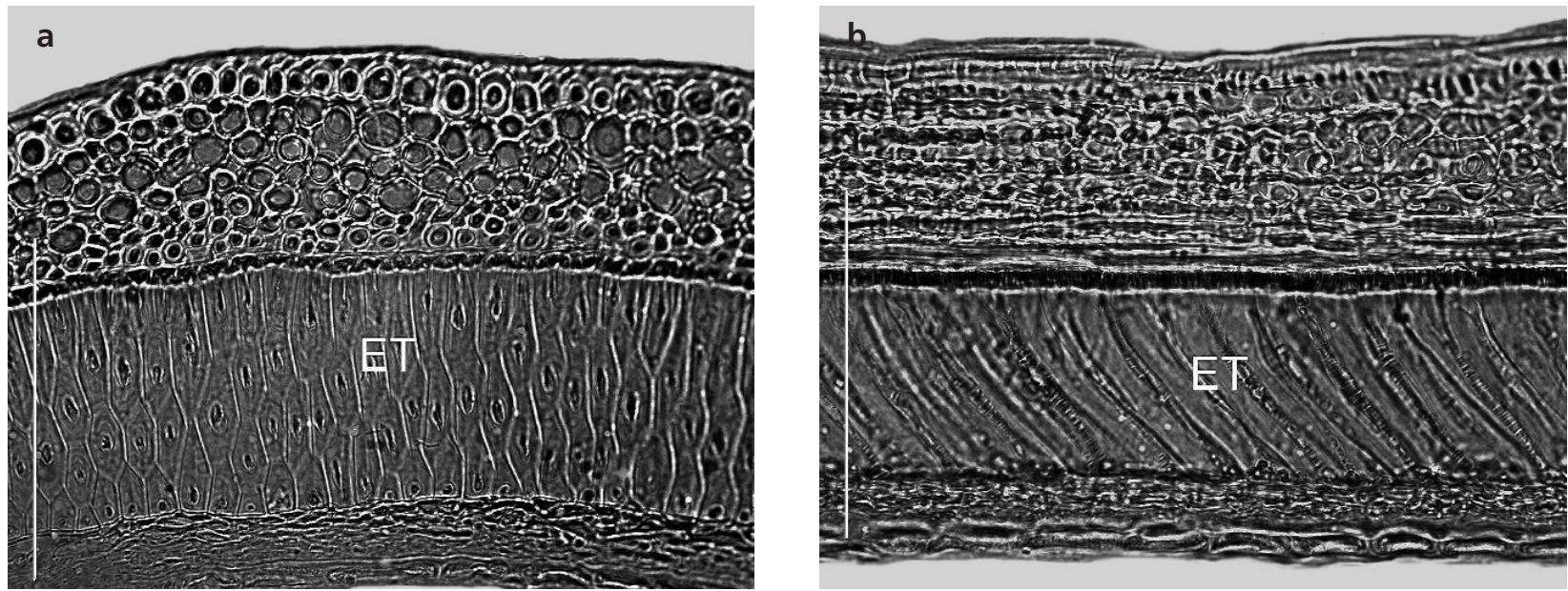

Fig. 2. Klasea centauroides: $\mathbf{a}$, cross section of achenes; $\mathbf{b}$, longitudinal section of achenes; ET, epidermal cells of testa. Scale bar: $0.1 \mathrm{~mm}$.
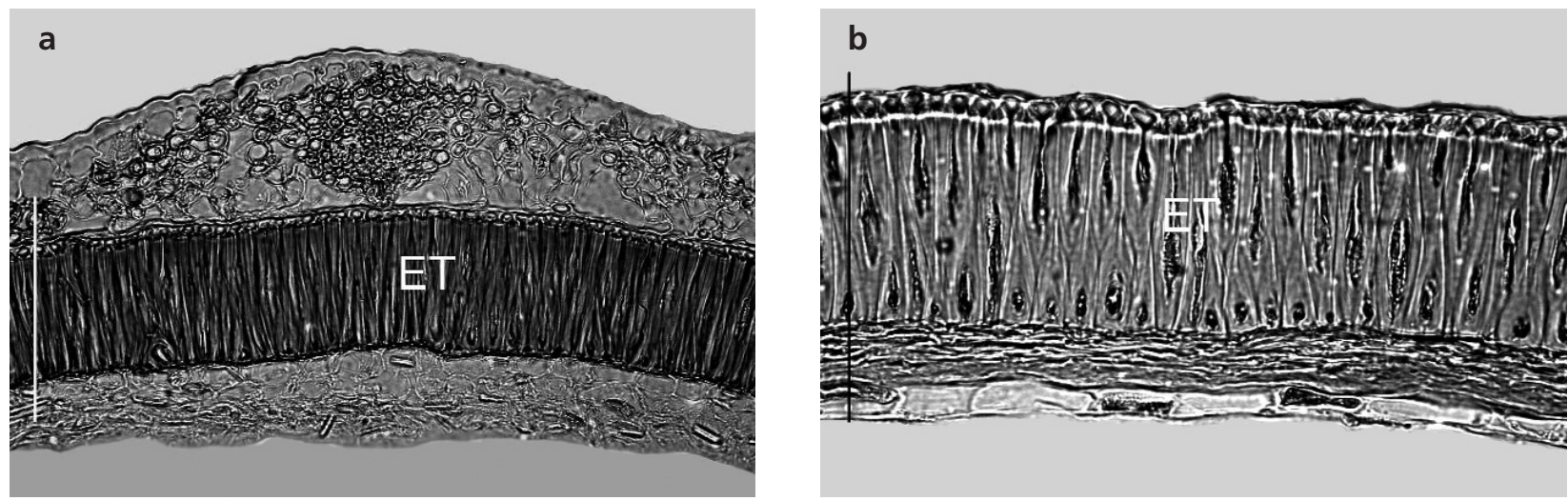

Fig. 3. Serratula manshurica: a, cross section of achenes; ET, epidermal cells of testa; b, epidermal cells of testa (cross section). Scale bar: $0.1 \mathrm{~mm}$.

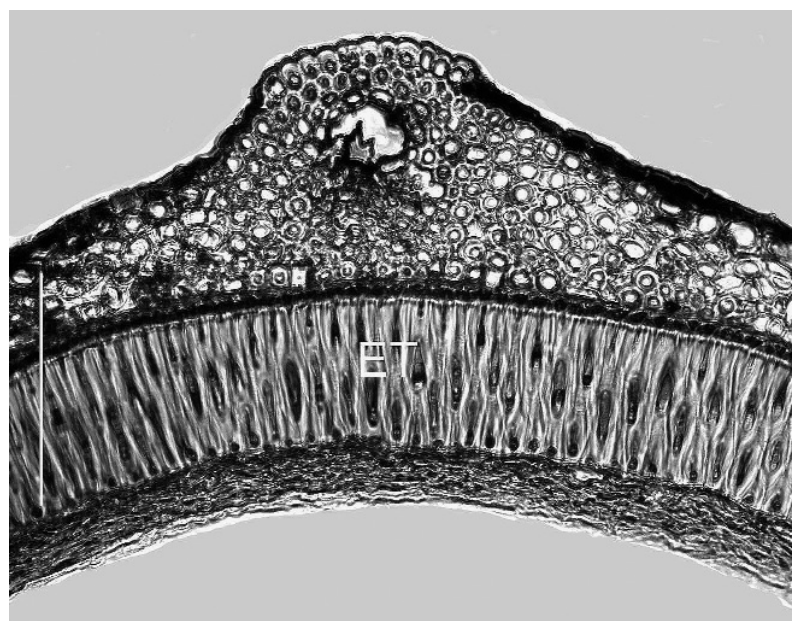

Fig. 4. Klasea komarovii (cross section of achenes): ET, epidermal cells of testa. Scale bar: $0.1 \mathrm{~mm}$.

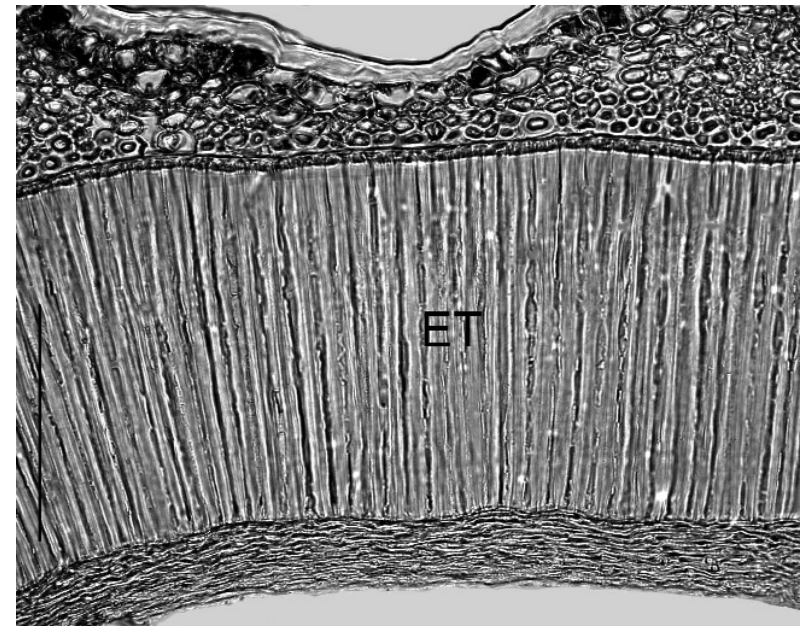

Fig. 5. Rhaponticum uniflorum (cross section of achenes): ET, epidermal cells of testa. Scale bar: $0.1 \mathrm{~mm}$. 
roides) or rectangular (S. komarovii) (cross section). The epidermal cells of mature achenes of $S$. manshuri$c a$ are thin-walled, cube-shaped, 10-25 $\mu \mathrm{m}$ wide and 8-15 $\mu \mathrm{m}$ high. In Klasea centauroides the epidermal cells are oval, slightly radially elongated, with uniformly thickened walls, 12-15 $\mu \mathrm{m}$ high and $13 \mu \mathrm{m}$ wide; in Klasea komarovii the cells are rectangular, 4-6 $\mu \mathrm{m}$ high and 10-25 $\mu \mathrm{m}$ wide, tangentially elongated, the cell lumen is filled up with phlobaphenes, therefore the achenes are dark brown.

The exocarp of the representatives of the Rhaponticum is formed by one row of epidermal cells. From the outside the fruit is covered with thick smooth cuticle up to $10 \mu \mathrm{m}$ wide. The epidermal cells are large, rectangular, tangentially stretched, thin-walled, $25 \mu \mathrm{m}$ wide and $15 \mu \mathrm{m}$ high (cross section), the cells are rectangular in longitudinal section, with inclined radial walls, up to $55 \mu \mathrm{m}$ long, the lumen of some cells is filled up with phlobaphene.

The epidermal cells of Synurus deltoides are cubeshaped, $12-15 \mu \mathrm{m}$ high and 10-18 $\mu \mathrm{m}$ (cross section) wide, rectangular in longitudinal section, up to $25-40$ $\mu \mathrm{m}$ long.

\section{Mesocarp structure}

In the studied species of Klasea and Serratula the mesocarp is rather peculiar and is represented by external (parenchymatous tissue consisting of several rows of thin-walled cells) and internal (sclerenchymatous tissue) layers. Besides, specific structures are formed in the mesocarp: calcium oxalate crystals and secretory ducts.

In mesocarp of Synurus deltoides some complex differentiation of tissues is observed. This is formed by parenchymatous cells with spiral thickenings (hydrocytes). Hydrocytic cells are prosenchymatous in longitudinal section, they form 44-50 rows. In the peripheral region of mesocarp they are significantly smaller in height than the cells adjacent to the testa. Moreover, $S$. deltoides is characterized by occurrence of calcium oxalate crystals and secretory ducts of schizogenous origin, which are located in the peripheral part of pericarp (Fig. 1).

In the mesocarp of the studied representatives of Rhaponticum the parenchymatous cells form 3-5 rows in the intercostals areas and 10-16 cell rows on ribs, they vary both in size and in the degree of wall incrassation. In the peripheral part of mesocarp the cells are thin-walled, large around the conducting bundles and, at the border with testa, there are smaller parenchymatous cells up to $7 \mu \mathrm{m}$ in diameter. The most incrassate are the walls of the cells directly surrounding the conducting bundles, in this region they are represented by typical sclerenchymatous cells. The thickness of the sclerenchyma cell walls reaches $2.5 \mu \mathrm{m}$. The parenchymatous cells at the border with testa also undergo intensive incrassation; in this region they are also represented by typical sclerenchyma cells arranged in 1-2, rarely 3 , rows. The cell diameter is 7-8 $\mu \mathrm{m}$. The conducting bundles of pericarp are located closer to testa.

\section{Secretory ducts}

Secretory ducts are of great importance in the taxonomy of the Cardueae s. 1. (Dittrich, 1977). Thus, Lavialle (1912) pointed out that in Serratula coronata L. the pericarp is entirely lacking in secretory ducts during all stages of achene development, which distinguishes it from the other species of Serratula such as S. tinctoria L. Secretory ducts are also absent in species of Klasea. Secretory ducts have been found in the species of the genera Amberboa (Pers.) Less., Carthamus (Chauhan, 1972; Singh \& Pandey; 1984), Centaurodendron Johow and Yunquea Skottsb. (Carlquist, 1958), Serratula, and species of some sections of Centaurea (Dittrich, 1977).

Secretory ducts of schizogenous origin lined with epithelium have been found in mesocarp in the studied species of Serratula and Synurus. In S. centauroides and $S$. komarovii, there are 4 secretory ducts located in the ribs of achene (Fig. 4). There are remains of conducting bundle elements under them. In S. manshurica secretory ducts have not been found. The same ducts have been revealed in the peripheral part of mesocarp in Synurus deltoides. Moreover, in one rib several (usually 2) small ducts are located, they are not connected with conducting bundles and do not influence the rib size.

\section{Crystals, their topography and localization}

In the inner layers of pericarp and testa there are crystals. The crystals are formed by calcium oxalate and have complex inner organization. Their occurrence has been recorded by many authors (Hanausek, 1911; Dormer, 1961, 1962; Gochu, 1973; Namba \& al., 1975; Singh \& Pandey, 1984). Dormer pays special attention to the physical characteristics of crystals: geometrical shape, average size, refraction index. In Dormer's $(1961,1962)$ opinion, the crystal type correlates with other morphological characters (pollen structure, occurrence of secretory ducts in the flower).

Crystals have been found in $S$. manshurica and $S$. komarovii in the inner region of mesocarp adjacent to the testa. The crystals of $S$. manshurica are polygonal in shape, 60-70 $\mu \mathrm{m}$ long and 4.5-5.5 $\mu \mathrm{m}$ high (Fig. 3 a). In $S$. centauroides the crystals have not been revealed. 
Synurus deltoides is characterized by needle-shaped crystals, 50-77 $\mu \mathrm{m}$ long, 7.5-7.7 $\mu \mathrm{m}$ high and located at the border between pericarp and testa.

\section{Testa epidermal cells topography}

Epidermal cells of testa (size, shape, their orientation regarding the achene surface in longitudinal and cross sections, radial wall thickening pattern) in the species of one genus are similar and are of no importance for species differentiation; they are, however, unique in structure and are a diagnostic character of genus.

The testa in the studied species consists of epidermis and several layers of mesoderm. Epidermal cells are macrosclereids with greatly incrassate walls, radially stretched and forming a palisade row of cells. The testa structure in the studied species of Serratula and Rhaponticum is similar to that of other representatives of the subtribes Centaureinae (Crupina, Carthamus, Amberboa, Centaurea) and Carduineae (Sylibum Adans., Cirsium, Saussurea). Such structure of epidermis is a constant specific character in the representatives of the subtribes Carduineae and Centaureinae (Dittrich, 1977). Besides, epidermal cells (longitudinal section) may be not precisely perpendicular to the achene surface, but also angularly, and this is observed in the species of Serratula we studied. This peculiarity can be revealed only in longitudinal section, since the cross section cuts several cell rows and the epidermis seems to be multirowed. Singh and Pandey (1984) investigated achene development in Carthamus oxyacantha Bieb., Centaurea moschata L. and Silybum marianum (L.) Gaertn., as well as anatomic structure of mature achenes in Carthamus baeticus Nym., Centaurea cyanus L., Onopordum algeriense Pomel., Saussurea albescens Hook. and Saussurea heteromella (Don) Hand-Mazz. and found out that in all studied species the testa epidermis was represented by a single row radially elongated, incrassate, lignified cells - macrosclereids. In longitudinal sections these cells are inclined at an angle towards the achene surface, therefore the epidermis looks multirowed (2-7 rows) in cross sections. This is observed in Carthamus oxyacantha, Centaurea moschata, Silybum marianum, Carthamus baeticus, Centaurea cyanus, Onopordum algeriense, Saussurea albescens and $S$. heteromella. The structure of epidermal cells was a reason for erroneous statements about testa multirowed epidermis being found in species of Carthamus (Hanausek, 1911; Ebert \& Knowles, 1968).

In all the species of Klasea and Serratula we studied, the testa is similar in structure and is a character connecting both genera. Due to the intensive radial growth and great secondary thickening of the wall, the epidermal cells turn into macrosclereids forming the palisade row of cells. Epidermal cells arranged at the angle $55-60^{\circ}$ to the achene axis (longitudinal section), as a result, the cross section cuts several cell rows and the testa appears multirowed in cross section (Figs. 2a, 3b). The radial cell walls are strongly incrassate (longitudinal section), as a result, a narrow channel remains in the cell, the outer and inner tangential walls are not incrassate. The cell lumen looks like a narrow channel widened in the area of tangential walls (longitudinal section).

In the species of Rhaponticum the epidermal cells of testa are narrow-rectangular, from 150 to $180 \mu \mathrm{m}$ high and $10-13 \mu \mathrm{m}$ wide, their radial walls are strongly incrassate (the walls reach up to $5 \mu \mathrm{m}$ thick), the tangential walls stay parenchymatic. The cell lumen looks like a narrow channel. In contrast to Serratula the epidermal cells of the representatives of Rhaponticum are oriented in radial direction (Fig. 5).

Synurus deltoides is characterized by a peculiar structure of testa epidermal cells. The epidermal cells of $S$. deltoides are oval in shape, thick-walled, uniformly incrassate (unlike Klasea, Rhaponticum and Serratula) with well-pronounced layering (the walls are 1.5-2 $\mu \mathrm{m}$ thick), the cell height is 3, 6-7 times (respectively) less than in the species of Serratula and Rhaponticum (cross section). In the longitudinal section the cells are rectangular (Fig. 1b), 130-160 $\mu \mathrm{m}$ long and tangentially elongated (in Serratula and Rhaponticum - radially).

As a result of our investigations on morphological and anatomic structure of fruit in the tribe Cardueae s.l. we determined that some characters can be diagnostic at the species level: 1) topography of epidermal cells of pericarp, 2) presence of phlobaphenes in them, 3 ) occurrence of calcium oxalate crystals, their topography and localization, 4) occurrence and location of secretory ducts in mesocarp. The diagnostic character of a genus is the structure of epidermal cells of testa (size, form, orientation, wall incrassation character).

\section{References}

Carlquist, S. 1958. Anatomy and Systematic position of Centaurodendron and Yunquea. Brittonia 10: 78-93.

Chargoglyan, A. A. 1975. Comparative anatomy of the achene covers in some representatives of the Centaurea L. Biologicheskiy Zhurnal Armenii 28(7): 53-57. (In Russian).

Chauhan, Y.S. 1972. Effect of gamma rays and 2,4-D on the structure and development of seed coat and fruit wall of Carthamus tinctorius L. Plant Science 4: 33-36.

Cherneva, O.V. \& Shurukhina, E.A. 1979. Analysis of the anatomical structures of covers achene of the genus Cousinia Cass. (Asteraceae). Botanicheskiy Zhurnal 64(12): 1738-1749. (In Russian).

Chernik, V.V. 1984. The development and structural features of achenes in Rhaponticum carthamoides and R. scariosum (Asteraceae). Botanicheskiy Zburnal 69(11): 1491-1497. (In Russian). 
Dittrich, M. 1968a. Karpologische Untersuchungen zur Systematik von Centaurea und verwandten Gattungen. Botanische Jabrbücher für Systematik, Pflanzengeschichte und Pflanzengeographie 88: 70-162.

Dittrich, M. 1968b. Früchtenatomische und zitologische Untersuchungen an einigen Arten der Gattungen Raponticum Adans. und Leuzea DC. (Compositae). Österreichisches Botanische Zeitschrift 115(4): 379-390.

Dittrich, M. 1968c. Morphologische Untersuchungen an den Früchten der Subtribus Cardueae-Centaureinae (Compositae). Willdenowia 5(1): 67-107.

Dittrich, M. 1970. Morphologische und anatomische Untersuchungen an Früchten der Carduinae (Compositae). I. Morphologischer Teil. Candollea 25(1): 45-67.

Dittrich, M. 1977. Cynareae -systematic review. In: Heywood, V.H. \& al. (eds.), The biology and chemistry of the Compositae 2: 999-1015. London.

Dittrich, M. 1985. Morphologische und anatomische Untersuchungen an Blüten und Früchten der Gattung Carlina (Compositae). I Teil. Botanische Jabrbücher für Systematik, Pflanzengeschichte und Pflanzengeographie 107: 591-609.

Dormer, K.J. 1961. The crystals in the ovaries of certain Compositae. Annals of Botany 25: 241-254.

Dormer, K.J. 1962. The taxonomic significance of crystal forms in Centaurea. New Phytologist 61: 32-35.

Ebert, W.W. \& Knowles, P.F. 1968. Development and anatomical characteristics of thin-hull mutant of Carthamus tinctorius (Compositae). American Journal of Botany 55: 421-430.

Fourment, P., Stanislas, E. \& Arnaud, J. 1956. Le fruit du Chardon a glu, Atractylis gummifera L. (Composees). I. Morphologie et structure des poilstecteurs. Bulletin de la Socété d'Histoire Naturelle de l'Afrique du Nord 47(5/6): 147-152.
Gochu, D.I. 1973. On the anatomy of seeds of some species of the genus Centaurea L. Botanicheskiy Zhurnal 58(2): 245-247. (In Russian).

Häffner, E. 2000. On the phylogeny of the subtribe Carduinae (tribe Cardueae, Compositae). Englera 21: 1-208.

Hanausek, T.F. 1911. Über das Pericarp und das Pericarpsekret der Gattung Carthamus. Berichte der Deutschen Botanischen Gesellschaft 29(2): 13-18.

Karawya, M.S., Hilal, S.H. \& El-Hawary, S.S. 1974. Macro and micromorphology of Centaurea calcitrapa L. Part 3. The fruit. Egyptian Journal of Pharmaceutical Sciences 15(3): 335-339.

Lavialle, P. 1912. Recherches sur le developpement de l'ovaire en fruit chez les Composées. Annales des Sciences Naturelles. Ser. 9. 15:39-149.

Namba, T., Kubo, M. \& Mikage, M. 1975. Studies on the medicinal resources from Taiwan. Journal of Japanese Botany 50(6): 180-189.

Pandey, A.K. \& Singh, R.P. 1977. Development and structure of seeds and fruits in the family Compositae -tribe Cynareae. Proceedings of the Indian Scientific Congress. Part. III: 101.

Pérez-García, F. \& Duran, J.M. 1987. Fruit anatomy of Onopordum nervosum Boiss. (Asteraceae). Phytomorphology 37(1): 35-38.

Singh, R.P \& Pandey, A.K. 1984. Development and structure of seeds and fruits in Compositae-Cynareae. Phytomorphology 34(1-4): 1-10.

Wagenitz, G., Dittrich, M. \& Damboldt, J. 1982. Centaurothamnus, eine neue Gattung der Compositae-Cardueae aus Arabien. Candollea 37: 101-115.

Associate Editor: A. Susanna

Received: 8-II-2007

Accepted: 14-III-2008 